\title{
INNOVATION AND COLLABORATION: THE ROLE OF THE NATIONAL GOVERNMENT IN NORWAY
}

\author{
XIANG YING MEI,* CHARLES ARCODIA,† AND LISA RUHANEN $\ddagger$ \\ *Eastern Norway Research Institute, Lillehammer, Norway \\ †Department of Tourism, Leisure, Hotel and Sport Management, \\ Griffith Business School, Griffith University, Gold Coast, QLD, Australia \\ $¥$ \$School of Tourism, Faculty of Business, Economics and Law, \\ The University of Queensland, Brisbane, QLD, Australia
}

\begin{abstract}
In recent years, innovation in tourism has become increasingly in focus as a strategy to gain competitive advantage. More studies in this area are still necessary as the role of the national government in such a process is still not well understood. This study focuses on the national government's role in stimulating networks and collaboration in order to encourage tourism innovation and its related activities. Based on the data gathered in Norway, the results of this study suggest that effective collaboration in terms of communication and networks is considered crucial in regard to tourism innovation at the national level. Four areas in which collaboration takes place were identified: collaboration within the government, public-private collaboration, collaboration among industry operators, and collaboration with other industries. Although its national government is keen to initiate such networks and collaboration, the results suggest that success is not solely determined by the national government. Public-private collaboration and encouraging collaboration among industry tourism operators have caught more government attention than the remaining two. Furthermore, the effectiveness of networks and collaboration as innovative processes to support tourism operators and contribute to destination development still needs to be further explored.
\end{abstract}

Key words: Norway; Innovation; Collaboration

\section{Introduction}

Studies concerning tourism innovation and destination competitiveness have grown significantly in recent years (Hall, 2009; Organization for Economic Cooperation and Development, 2006). Research in this area is, however, mostly scattered and fragmented, with little focus on the role of national government as facilitator in such a process. The nature of innovation as a systematic phenomenon suggests that continuous involvement between different actors and organizations (Coombs \& Miles, 2000; Edquist \& Lundvall, 1993) is necessary. Tourism, more than most other economic sectors, requires formal and informal collaboration, as destinations 
are often described as articulated groups of independent suppliers who work together to deliver the overall tourism product.

Innovation through collaboration has been addressed in many studies; however, these are often discussed in regard to collaboration within an organization or within a local region with little or no emphasis on assistance from the government (Hjalager et al., 2008; Kelliher \& Reinl, 2011). As the tourism industry is generally dominated by small and medium-sized enterprises (SMEs) that are arguably considered noninnovative due to their simple management processes and scant focus on long-term strategies (Jeffries, 2001; Keller, 2006), the importance of collaboration and innovation to achieve competitiveness becomes less obvious for these operators. Thus, the national government plays a crucial part in stimulating such networks and collaboration in order to facilitate tourism innovation at the national level.

There is a significant research potential in this area as there is a paucity of studies focusing on tourism innovation on a national level and particularly the role of the national government. A qualitative study was undertaken to conduct an analysis of relevant tourism policy documents along with a series of in-depth interviews with key government officials both at the national and at the regional levels in Norway. The research objectives of this study are first, to establish the extent to which the national government engages and collaborates with the industry, and second, to establish the means by which it stimulates collaboration within the tourism industry in order to facilitate innovation. The findings contribute to a deeper understanding of government-facilitated collaboration activities in regard to tourism innovation. This study, however, does not seek to examine how collaborations affect specific types of innovation but rather focuses on the national government's role in such a process.

\section{Literature Review}

\section{Innovation in Tourism}

Innovation has rapidly emerged as an important strategy to achieve destination competitiveness. It has been argued that through innovation a destination has the ability to create change, core competencies, and unprecedented value by providing something different and new (Kim \& Mauborgne, 1997; Moscardo, 2008). Subsequently, this will ultimately lead to distinctive and inimitable competitive advantages that result in economic gain. Innovation is often described as the process of developing new products or processes, as well as accessing new markets or new suppliers, and the implementation of new methods or organization (Hall \& Williams, 2008; Hjalager, 2002, 2010; Schumpeter, 1934).

In addition to the various categories of tourism innovation, which often include product or service, process, and management (Hjalager, 2010), innovation can also be described as incremental or radical, which is used to classify the level of newness of an innovation. Johne (1996) emphasizes that truly innovative ideas are those that are new to the world by arguing that incremental innovations do not deserve to be called innovations at all. It is therefore suggested that innovations in terms of modest improvements, cost reduction strategies, line extensions, repositioning, or repackaging cannot be considered as innovations. Hjalager et al. (2008) also point out that although innovation is related to newness, the literature does not precisely describe how different or revolutionary a new idea should be in order to be called an innovation. The typical perception is that an innovation needs to be radical, groundbreaking, and different in order to be considered innovative (Hjalager et al., 2008). Researchers including Poon (1993), Storey and Salaman (2005), and Utterback (1994) disagree by arguing that innovations can be classified either as radical or as incremental in order to determine the level of newness. Garcia and Calantone (2002), similar to Kleinschmidt and Cooper (1991), also stress that there is a third category of innovation that lies in between radical and incremental that has received less attention by academics. One of the reasons for this is that radical or incremental innovations are considered to be more successful than moderate and in-between innovations (R. G. Cooper, 2001; Kleinschmidt \& Cooper, 1991; Nohria \& Gulati, 1996). Nevertheless, researchers who attempt to rate the success of innovations generally focus on the manufacturing industry and on industrial product firms.

Garcia and Calantone (2002) further stress that radical innovations that revolutionize the world are 
generally rare because they cannot be planned or predicted. Therefore, incremental innovations are more common and achievable. Despite the fact that they are regarded as "low innovative" and disregarded by some researchers as innovations, incremental innovations are of vital economic and competitive importance as they are directly related to efficiency and cost (Utterback, 1994).

The definition of innovation remains debatable because newness as the essence of innovation is not easily measured (Avlonitis, Papastathopoulou, \& Gounaris, 2001; Garcia \& Calantone, 2002). In addition, new and innovation are used interchangeably in some literature because it is often difficult to separate these two concepts (Hassanien \& Eid, 2007; Laange-Hellman, 1987). From such discussion, it is suggested that innovation needs to have some degree of newness, but a product or process is not necessarily an innovation if it is simply new and nothing else beyond. For the purpose of this study, innovation has been conceptualized as a new activity that leads to changes in processes and products or services, either incremental or radical, that ultimately results in some degree of economic gain (Hall \& Williams, 2008).

Innovation has not traditionally been considered relevant in non-knowledge-intensive sectors such as tourism. Recently, however, researchers and practitioners particularly in advanced destinations have recognized the importance of tourism innovation for destination competitiveness due to globalization and fierce competition from emerging destinations with cost advantages (Camisón \& Monfort-Mir, 2012; Hall, 2009; Hong, 2008). The growing number of studies in the service sector has also undoubtedly contributed to the facilitation and adaptation of innovation in the tourism industry that is clearly service oriented. Nevertheless, a majority of the studies are mostly focused at the firm level in the private sector, although the importance of addressing innovation at the destination level has been gaining importance in recent years.

\section{Government, Collaboration, and Tourism}

The complexity of the tourism industry requires coordination and cooperation, which arguably only governments have the authority and ability to provide. The involvement of the public sector is thus crucial in order to secure a sound long-term development of the tourism industry (Dredge \& Jenkins, 2007; Hall \& Williams, 2008; Jeffries, 2001). The role of government in the general tourism industry can range from simply coordinating private sector investment decisions to use taxes or subsidies to support market prices and to create public enterprises (Rodrik, 1996). Furthermore, Hall (2008) argues that the national government has various functions and areas of responsibility in tourism including coordination, planning, legislation and regulation, entrepreneurship, promotion, social tourism, and interest protection. The reasons for government involvement in tourism is well summarized by Jeffries (2001), who explains that first, "governments are essentially drawn by the actual general legislations and policies such as taxes and their effects on tourism," and second, "policies, legislations and programs may be supported by government with tourism as their central focus” (p. 103).

Although globalization has reduced the level of involvement by national governments in contemporary society, the state is never totally absent (Hall, 2008). Both governments and firms have resource dependencies, and their goals can seldom be achieved single-handedly. The regulatory framework in which private and public activity occurs is set by the state (Dredge \& Jenkins, 2007). Government also has an important role as it is responsible for the overall coherence of the national systems of innovation as well as the social system (Dalum, Johnson, \& Lundvall, 1992). Hence, the government remains as the governing authority that establishes and enforces the rules under which organizations operate. Without the involvement of the government, the destination may experience market failure caused by failures in some subsections, affecting the success of the industry in general (Jeffries, 2001). Moreover, government involvement in innovation is important as it underpins a number of activities within systems of innovation that act to reduce the levels of uncertainty felt by actors within the private sector (Hall \& Williams, 2008). Individual operators also need the assistance of government programs to develop and commercialize an innovation, as the private sector may not have the necessary competence, resources, and legitimacy particularly in a national or destination context (Van de Ven, Polley, Garud, 
\& Venkataraman, 1999). Government involvement needs to be better defined, however, as failures in innovation occur not only because of the inability or unwillingness of the government to facilitate and promote the growth of network structures but also because it seeks to retain its position of power and control (Breznitz, 2006).

A destination is largely based on "free goods" and therefore requires numerous actors to collaborate and compete at the same time in order to create the complete tourism product. These free goods include natural resources, cultural attractions, and other attributes, including townscapes that are not owned or managed by a single company but are a part of a tourism system (Crouch \& Ritchie, 1999). Thus, networks and communication between these organizations become essential in innovation activities. Such organizations may include firms, laboratories, academic institutions, consumers (De la Vega \& Stankosky, 2006), and other key players in both the private and the public sectors (Van de Ven et al., 1999). In regard to governments in stimulating collaboration, numerous studies have focused on the importance of collaboration in tourism, and the nature of such collaboration has also gained significance in tourism innovation studies (Hjalager, 2009; Presenza \& Cipollina, 2010; Romeiro \& Costa, 2010). Collaboration between the private and public sector is arguably crucial because the essence of innovation suggests that it does not occur in isolation. The growing complexity of the knowledge bases necessary for innovation implies that even large firms increasingly depend on network and external sources in their innovative activity. As it is unlikely that tourism operators and SMEs in particular will initiate networks and collaboration opportunities on their own (Kelliher \& Reinl, 2011; Morrison \& Teixeria, 2004), government involvement becomes crucial in stimulating such collaboration.

Despite the importance of the government and public-private collaboration, there is currently poor understanding of the national government's role as a facilitator in tourism innovation. In addition, there is still a research gap in this area particularly focused on a national scale. As governments worldwide are also slowly acknowledging the importance of tourism innovation for destination competitiveness and national wealth (Hall, 2009), studies that seek to gain understanding of the government's facilitating role in innovation are considered to be valuable. A majority of existing studies are either mostly focused on local governments, limited to a specific region, or lack empirical findings. There is therefore a need for empirical evidence.

\section{Research Methodology}

A qualitative study was undertaken in the form of a review and analysis of policy and a series of in-depth interviews. The interviews were the main data collection method, whereas the review of key policies helped to understand the situation relevant to the research objectives (Paget, Dimanche, \& Mounet, 2010). Policy review also provided some background information and foundation to develop the interview schedules. This triangulation of the data ensured the validity of the research (Myers, 2009).

In-depth interviews aimed to collect data from key government officials at the national and regional level as well as industry representatives and operators in Norway. The in-depth interview was chosen as the main data collection method because of its ability to provide richness, credibility, and value as well as its usefulness in pursuing a topic in depth (Henderson, 1991). The interviews were designed to be semistructured in order to allow participants to speak freely about the issues related to the research objectives. Two sets of interview schedules were developed, and the questions were designed to be predetermined and open ended. This enabled the researcher to further explore topics and discover possible discrepancies. In addition, the questions emerged from an analysis of existing literature in the field, and the questions were justified because they are reflective of key issues raised in the literature.

The data gathered from both the policy review and the in-depth interviews were subjected to content analysis in order to handle and organize the large amount of data (Patton, 1990). Such methods are a widely used qualitative analytic approach, as they enlighten and enrich the understanding of text (Berno, 1996; McNabb, 2002). The actual process involves organizing data into various categories based on key themes, concepts, or other similar features. In addition, new features can also be developed when new conceptual definitions are 
formed and relationships among the key concepts are examined (Jennings, 2001; Neuman, 2006).

\section{Method}

The data collection was conducted in Norway, an advanced but not yet mature destination. The national government in Norway has since 2004 been a strong advocator of innovation as a strategy for tourism development (Hall \& Williams, 2008). The country does not currently have a Ministry of Tourism as tourism-related industries are facilitated by the Norwegian Ministry of Industry and Trade, while Innovation Norway acts as the operating authority. The fairly simple government structure of Norway and its low population number allowed a national study to be conducted. The policies were selected on the basis of a purposive method to only include key tourism policy documents that are relevant to the research objectives. They range from 2004 to 2010 and contain perspectives specifically related to innovation and collaboration within tourism. In total, six key national tourism policy documents and one indirect tourism policy were sourced online on the official joint website. Two separate interview schedules were then developed on the basis of the information gained from the policies and the literature review. In total, 34 interviews were conducted with 12 government respondents $(G)$ and 22 industry respondents (I) as participants. The respondents were selected on the basis of their understanding and knowledge of the national government's role in tourism development, and the interviews were carried out in a semistructured manner.

\section{Results and Discussion}

The results of the study indicate that there are various areas in which the national government initiates collaboration-related activities within the tourism industry to facilitate innovation. Tourism innovation at the national level may face similar challenges as the tourism industry in general. This is contributed by the complexity and characteristics of the tourism industry, which is not an industry by itself but is composed of many industries (Frechtling, 1999), and thus require collaboration in order to achieve destination innovativeness (Nordin \& Svensson, 2005; Pechlaner, Fischer, \& Hammann,
2005). The findings support such a claim by verifying the role played by the national government. One key finding is that effective collaboration in terms of communication and networks is considered crucial in regard to tourism innovation at the national level. Essentially, this study has identified four areas in which the national government plays a crucial role in facilitating tourism innovation by encouraging collaboration as demonstrated in Figure 1.

1. Initiate communication and collaboration within the government itself and between the ministries and other government organizations involved in tourism development.

2. Initiate effective communication and collaboration opportunities between the government and the industry.

3. Encourage networks and collaboration within the tourism industry between operators and among multiple operators.

4. Provide opportunities for networks and collaboration with other industries.

The solid dark lines in the figure display the four forms of collaboration relevant to this study. The figure illustrates the areas in which the national government provides funding and support to stimulate collaboration. The dotted dark line indicates that there are no significant funding and supporting activities contributed by the national government at present, but such support may be necessary. Each of the collaboration forms are discussed in detail.

\section{Collaboration Within the Government}

The findings indicate that effective coordination across various ministries and other relevant government organizations is a key factor in facilitating tourism innovation. As discussed, tourism activities are embedded in other areas and industries including transport, infrastructure, education, environment, food, culture, finance, trade, and foreign affairs. Such a situation is particularly challenging to the tourism industry in Norway as there is currently no Ministry of Tourism. In addition, as governments are composed of a range of departments and agencies with different priorities, agendas. and culture (Dredge et al., 2010), similar challenges may exist in other countries as well. All 34 respondents 


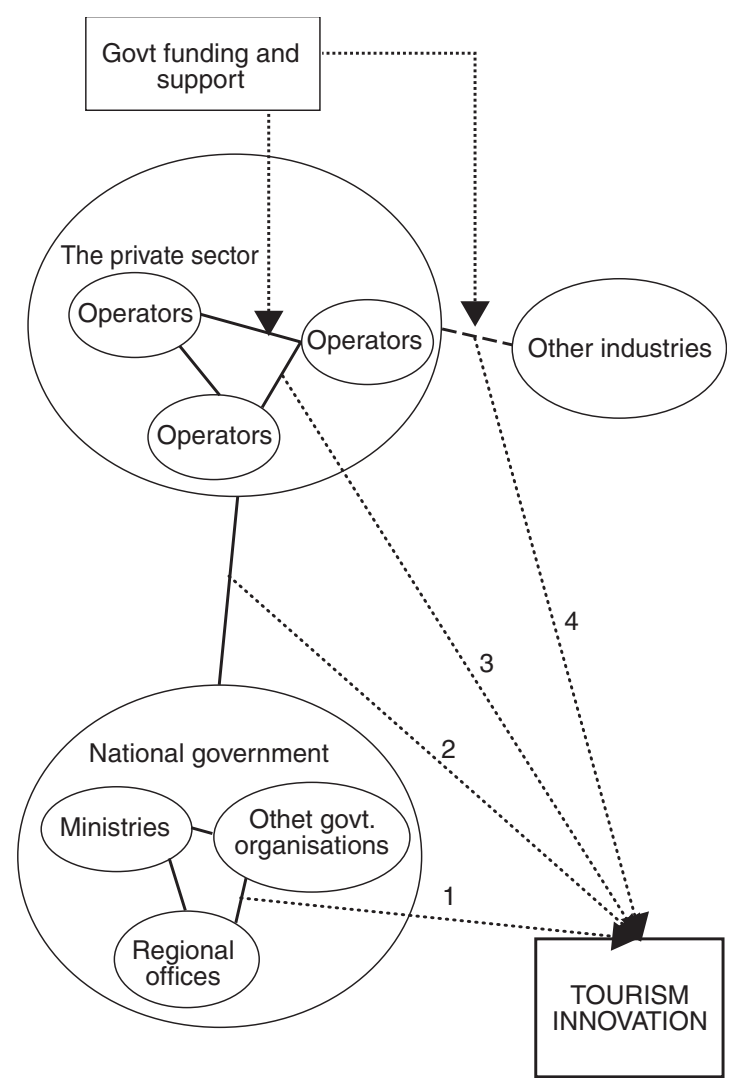

Figure 1. The role of the national government in facilitating collaboration.

revealed that the government's ability to effectively communicate and collaborate among themselves is crucial in facilitating tourism innovation. It was also expressed that close collaboration is important in regard to policy development at the national level.

Everything can be better, but the problem is that there are many tasks within many ministries that have great influence on an active tourism policy; therefore coordination becomes extremely important and a strong coordination will have great impact on the tourism industry and not least innovation if that's what they keep saying they want. (I12)

In addition, all respondents were positive about the latest national tourism policy, which was developed in collaboration with nine other ministries.

When the national tourism strategy was formulated, it was formulated by nine ministries together and that's the first time it has ever happened. I think that they have managed to [develop] a joint strategy because otherwise it's mostly NHD [Ministry of Trade and Industry] that makes them. And yes of course this is positive for tourism development and innovation. (G5)

In the latest national tourism policy, "Valuable Experiences," the national government also emphasized the importance of working with other ministries in order to facilitate tourism innovation as "food, cultural landscapes, and art and cultural activities and institutions play an important role in tourism and product development in the tourism industry, and a number of programs administered by various ministries aimed at specific sectors can also contribute to innovation in tourism" (Norwegian Ministry of Trade and Industry [NMTI], 2007, p. 19). Although the coordinating role is a prime responsibility of the national government in tourism in general, such an intervention may have a great impact on tourism innovation (Hall, 2008; Hall \& Williams, 2008). Respondents provided many positive examples of collaboration within the government that have greatly improved.

The thing is the tourism industry is very dependent on, for instance, transport and when it comes to this area Ithinkthat theministrieshavegraduallybecome better at talking with each other. They are becoming better at seeing the positive effects of doing things together but it's moving very slowly. (I1)

Although a majority of respondents believed that the government's approach is appropriate, the remaining 10 respondents stressed that such activities need to be further improved in order to increase innovation.

Politically I think that we need to improve the coordination with other public actors in terms of tourism development. We don't have our own ministry of tourism so coordination becomes crucial for our development and of course innovation. (G10)

I think they work well in various areas but there is still great potential to develop coordinating and collaborating work between the various ministries. (I9)

The importance of collaboration within the government as a means to facilitate tourism innovation has not been as widely discussed in the literature in comparison to the collaboration between the private and public sectors as well as collaboration among industry operators within the industry. The findings suggest that effective collaboration within the 
national government will greatly affect its ability to facilitate tourism innovation. As the national government often has overlapping and conflicting roles (Hall \& Williams, 2008), it is logical to argue that effective collaboration and communication within the government ministries and other government organizations are crucial to facilitating tourism innovation.

\section{Public-Private Collaboration}

Collaboration between the public and the private sectors is an area that has received the greatest attention in the literature (De la Vega \& Stankosky, 2006; Van de Ven et al., 1999) in addition to networks and collaboration between operators in the tourism industry. Public-private sector collaboration are, however, not exclusive to tourism innovation. Numerous studies that argue the importance of collaboration between the private and the public sectors in regard to tourism development and planning often have done so without specifically including the word "innovation" (Hall, 2008; Presenza \& Cipollina, 2010). The very nature of such collaboration may nevertheless lead to innovation (De la Vega \& Stankosky, 2006; Hall, 2009). The tourism policies also indicated that public-private collaboration has been emphasized often without specific references to the innovation, as "a coordinated effort with collaboration between private and public sectors has proven to be one of the success criteria in regions and countries where it has succeeded in tourism investment” (NMTI, 2007, pp. 38-39). Although the word innovation is not mentioned in the statement, it was acknowledged in the policy document that success in the tourism industry requires a close interplay between the public and the private sectors. Hence, it can be assumed that successful tourism innovation would also require such collaboration. This is further echoed in the White Book for Destination Development, as "good collaborative relationships between tourism operators and Innovation Norway are also important goals for stimulating innovation and creativity at the destinations" (Innovation Norway, 2008, p. 9).

The literature states that public-private collaboration is crucial for tourism innovation (Nordin \& Svensson, 2005; Pechlaner et al., 2005). Although there are few studies focused on the national scale, the current study suggests that collaboration is also imperative at the national level. Although collaboration should arguably be quite natural, hostility between the public and private sectors often exists because of a lack of understanding of each other's role. The argument is that the government lacks sufficient knowledge of the industry as well as other conflicting interests (Bramwell \& Lane, 2000). Collaboration with the government is also thought to be difficult, with lack of direct communication channels as indicated by 10 industry respondents.

\section{We need more forms of communication because today it's mostly some speeches at parties and some seminars and that's it! We at the grassroots have no contact with the national government whatsoever. (I5)}

This affects the industry operators' ability and willingness to collaborate for innovation. The government respondents, however, did not see this as a challenge because they believed that a close relationship currently exists. There are also contradictory claims as six industry respondents did not believe that a direct communication channel is necessary. These respondents believed that it is better to communicate with the national government through a trade association. A trade association may have a better overview of the gaps in the innovation environment and other tourism development needs than the individual industry operators (Etzkowitz, 2003). Nevertheless, five industry respondents thought that communicating through a trade association may actually inhibit innovation. Essentially, it is believed that one of the key trade associations has a too close relationship with the national government and therefore is unable to be critical.

The people who deal with the national government the most are NHO Reiseliv (Norwegian Hospitality Association) after all. And they have a very good dialogue [with the national government]. I think it's almost too good sometimes as they become too much like colleagues. (I7)

As the issues disseminated in the trade associations' press and at their meetings and conferences are often only selected topics (Hjalager, 2002), respondents fear that this challenges tourism innovation and its overall development. The role of 
trade associations in tourism innovation is a topic that may need to be further explored but is beyond the scope of this study.

When collaboration is considered, industry respondents stressed that a partnership is the ideal way to work with the national government. Such findings are consistent with several studies (Breznitz, 2006; Hall \& Williams, 2008) and also particularly relevant in advanced countries such as Norway (Bramwell \& Lane, 2000; Mahmood \& Rufin, 2005). Others have argued that a more prominent role for the national government in the form of leadership is needed to provide a better ability to create an innovative and competitive destination (Hall \& Williams, 2008; Pechlaner et al., 2005). However, although 10 industry respondents indicated that collaboration activities need to be improved, none of the respondents stated that they wish to see more leadership or more direct involvement from the national government. This may be due to the structure of Norwegian society where a bottom-up approach is embraced. Such findings are also echoed by Mahmood and Rufin (2005), as governments' involvement with the private sector depends on the level of advancement of the country. Also consistent with the literature, tourism innovation at the national level requires initiatives from both the private and the public sectors as tourism innovation capability is not solely determined by the national government (Hall \& Williams, 2008). The findings therefore concur with Nordin and Svensson's (2005) study, although it was merely regionally focused. This study supports the importance of the national government's involvement in tourism innovation at a national level. The following section explores collaboration among the tourism operators and the role of the national government to stimulate such collaboration.

\section{Collaboration Among Industry Operators}

Although the two forms of collaboration previously discussed are considered important when highlighting the national government's facilitating role, all 34 respondents recognized that collaboration in terms of networks among operators themselves is the most influential way to stimulate tourism innovation. This also means collaboration with competitors (Etzkowitz, 2003), which respondents stressed as challenging.
Networks and collaboration in the tourism industry are difficult. That's not the tradition. Traditionally it has been up to each one of the operators to do whatever they want, to go their own way. But in recent years they have realized that collaboration is important but they have to practice on how to collaborate because that's not the tradition. (G10)

Although the respondents acknowledged that collaboration is important for tourism innovation, it was argued that it is generally difficult to achieve.

I think some will see the benefits of collaboration, but I think a majority still see others as their competitor and not necessarily someone who can contribute to strengthen the product. (I15)

Despite such challenges, this study reveals that tourism policies as well as government and industry respondents unanimously recognize and agree that networks and collaboration among operators are important for tourism innovation. Such finding is consistent with several other studies (Bieger, 2005; Carlsen, Liburd, Edwards, \& Forde, 2008; Presenza \& Cipollina, 2010) and also recognized by government respondents.

It [networks and collaboration] is particularly important for the tourism industry because we are dependent on the complete product where numerous operators contribute to an experience. That's how innovation comes into the picture. (G9)

Studies have stressed that governments offer various programs to encourage industry collaborations (Australian Institute for Commercialisation, 2010), and this is also correct in the case of Norway as the national government recognizes that networks and collaboration among operators are crucial for tourism innovation. Norway's tourism policies encourage innovative projects in terms of networks and collaboration, and this was also verified by government officials.

The government sees networks as important to stimulate innovation in the Norwegian tourism industry and will continue to set requirements that innovative projects in tourism through Innovation Norway are collaboration and/or network projects. In this way the Government helps to strengthen the interaction between industry, knowledge of operators and the public. (NMTI, 2010, p. 140) 
For instance, the national government has initiated programs to encourage such networks and collaboration by offering incentives in the form of financial support and funding. More importantly, all government respondents emphasized that the most important role the national government has in facilitating tourism innovation is to stimulate networks and collaboration.

We will support projects that are innovative. Very often they [operators] can get support from us if they have projects that are internationally focused and that there are at least three operators collaborating together to make sellable products. (G5)

In regard to the national government's current approach to stimulate collaboration among operators, 10 industry respondents were generally satisfied with its efforts, whereas the remaining respondents were critical, with six respondents questioning its usefulness.

I think it's right for the national government to come in and we get to speak with each other. And they often do that to tempt us, for instance, if you guys collaborate together then you will get the funds and supports [sic]. And that has been done several times to create new projects and organizations which last 3-4 years, then there are no more funds and they terminates [sic] and we've come just so far. (I10)

Hence, the effectiveness of such initiatives was questioned. This is consistent with Novelli, Schmitz, and Spencer (2006), who argue that there are limited studies on whether networks can be used as an innovative process to support tourism operators' projects and contribute to destination development. A further five industry respondents stated that they are not aware of any initiatives from the national government as it is mostly the operators themselves who have initiated many successful collaborations. Similar to public-private collaboration, collaboration between various operators often occur without government involvement (Buhalis, 2000; Faulkner \& Tideswell, 2005). Therefore, networks and collaboration are also not exclusive to innovation.

Essentially, 18 respondents believed that the success of such collaboration depends on the tourism operators themselves. The national government can only facilitate and encourage such processes but it is not the government that determines success. This can, however, be challenging when operators still consider other operators as competitors rather than collaborating partners.

Successful collaborations require an inner force from the operators who actually want to collaborate with others. We have tried the opposite, where we actually have been too involved and tried to facilitate and stimulate but it hasn't been a success. (G8)

The national government can facilitate but it's the operators themselves who have to implement it. You can't just decide to have a network, it has to be created. (I11)

The literature argues that tourism operators need to compete and collaborate at the same time to become competitive at the national level (Christensen, McIntyre, \& Pikholz, 2002). The challenge according to all government respondents is to make the operators realize that collaboration is crucial for tourism innovation. Previous studies have also found that collaboration is imperative for the sharing and obtaining of knowledge in order to innovate (C. Cooper, 2006; Hall \& Williams, 2008; Nordin \& Svensson, 2005). The findings further reveal that the success of such collaboration depends on the level of knowledge and expertise of the operators highlighted by 18 respondents.

Networks and collaboration occur when you see the value of them. And if you have low skills and knowledge, it's difficult to see the benefits of them before trying. (I1)

This is echoed by Carlsen et al. (2008), who recognize a lack of knowledge as a potential internal barrier to innovation. Hence, as illustrated in Figure 2, it can be suggested that knowledge and collaboration are dependent on one another in order to stimulate tourism innovation.

\section{Collaboration With Other Industries}

The final form of collaboration was not raised by all the respondents particularly government respondents at the national level. Nevertheless, collaboration with other industries was emphasized as crucial for tourism innovation by 20 respondents. This issue was not highlighted in relevant tourism 


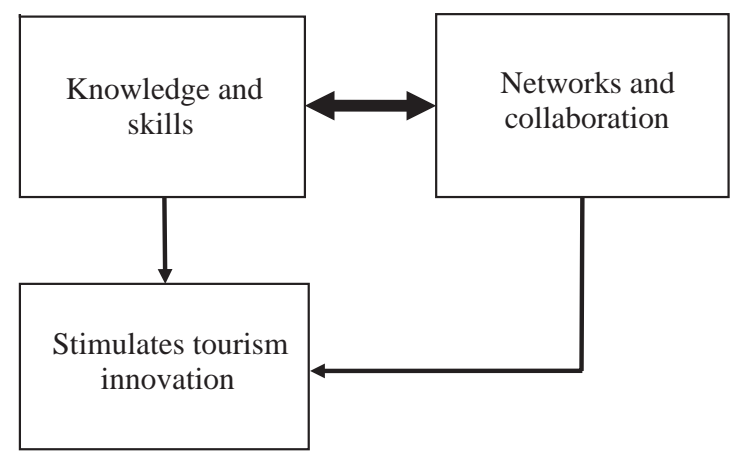

Figure 2. Factors that stimulate tourism innovation.

policies, although the national tourism policy did acknowledge that "innovation in tourism will primarily occur in the overlap with other industries, such as agriculture, fishing and culture" (NMTI, 2007, p. 22). This could be an indication that the national government has yet to recognize the importance of the tourism industry collaborating with other industries for innovation. Nevertheless, one example of collaboration with another industry was provided in Valuable Experiences, although this has only referred to the marketing side.

The use of films as a promotional tool is a new approach for the Government. The Government has granted NOK 1.5 million for a pilot project of Naturvisjon which shall become a series of nature documentaries for television and the cinema. (NMTI, 2007, p. 68)

As discussed, new knowledge is essential for innovation (C. Cooper, 2006; Hall \& Williams, 2008; Hjalager, 2002), and respondents agreed that one way to obtain new knowledge is by collaborating with other industries.

I think the industry needs to be better at collaborating with networks within other sectors. Not only within the tourism industry because the tourism industry can learn from other sectors as well. I think this must occur to stimulate even more innovation and new product development etc. (G4)

Hall and Williams (2008) stress that knowledge sharing via collaboration with other industries as a means to innovate is widespread in many sectors. Although this is not the tradition in the tourism industry, such partnerships may be necessary to develop innovative tourism products and services. For instance:

If you look at the big perspective, Disney World and Universal Studios or something like that, the big brands they work together like IBM and Kodak and those things. They work with experienced industries to create good experiences and innovative products. (I19)

As discussed, because collaboration within the tourism industry was described by the industry respondents as difficult to achieve, collaboration with other industries may thus be even more difficult to achieve. This is also arguably more challenging when the national government has yet to recognize the importance of such collaboration. Therefore, there are currently no programs or initiatives to stimulate such "nontraditional" collaboration activities from the government's side. Roper and Crone (2003) further argue that in order for such collaboration to be successful, they should be more than simple activities of trading because the industries involved must see the value of such synergy. The national government as the guarantor of the wider nation may arguably adopt more of a leadership role in this context in order to foster such partnerships (Etzkowitz, 2003; Metcalfe, 1994).

\section{Conclusion}

Although previous studies have focused more on networks and collaboration among the operators within the tourism industry and private-public collaboration in regard to tourism innovation, the findings reveal that effective collaboration within the government and among the relevant ministries and organizations are also crucial. This study concludes that collaboration among government ministries and organizations impact on how well the national government engages and collaborates with the industry to facilitate tourism innovation. Hence, effective collaboration within the government itself is crucial for tourism innovation.

The study further reveals that direct communication opportunities are more effective for the national government to collaborate with the tourism industry. This is because communication via trade associations may inhibit tourism innovation as only selected issues are raised. As networks and 
collaboration among the operators remain as the most important form of collaboration, the findings suggest that active involvement from the national government to encourage and stimulate such collaboration is needed. Nevertheless, the operators themselves must have the drive to sustain such networks. The national government should therefore encourage such collaboration, but the importance of such networks must first be recognized and valued by the national government.

This study does not suggest that collaboration among the industry operators as well as collaboration with other industries cannot occur without the involvement of the national government. Nevertheless, additional stimulus from the national government may be required in order to further encourage such a process. The findings also verify that the national government does have a significant role to play, but such a role remains a facilitating one, as the success of such networks and collaboration is not determined by the national government. Based on this, future studies that consider the roles played by the various actors within the tourism industry, including trade associations, would be valuable to further explore this topic. It should be noted that despite the many initiatives by the national government to stimulate collaboration for tourism innovation, the success of using networks as innovative processes to support tourism innovation among operators is still unclear. More specific studies that investigate how collaboration can affect various types of innovation may be required. Although the result of this study has derived from a specific sample, it is believed that its findings can be applied to other countries of similar governmental structure and tourism development.

\section{References}

Australian Institute for Commercialisation. (2010). Innovation and government. Retrieved June 10, 2010, from http://ausicom.com/filelib/Innovation_in_the_Public Sector.pdf

Avlonitis, G. J., Papastathopoulou, P. G., \& Gounaris, S. P. (2001). An empirically-based typology of product innovativeness for new financial services: Success and failure scenarios. Journal of Product Innovation Management, 18(5), 324-342.

Berno, T. (1996). Cross-cultural research methods: Content or context? A Cook Islands example. In R. Butler \& T. Hinch
(Eds.), Tourism and indigenous peoples (pp. 376-395). London: International Thomson Business Press.

Bieger, T. (2005). Competitive advantage of industries and destinations. In P. Keller \& T. Bieger (Eds.), Innovation in tourism-Creating the customer value (Vol. 47, pp. 229-244). St. Gallen, Switzerland: AIEST.

Bramwell, B., \& Lane, B. (Eds.). (2000). Tourism collaboration and partnership: Politics, practice and sustainability. Clevedon, UK: Channel View Publications.

Breznitz, D. (2006). Innovation and the state: Development strategies for high technology industries in a world of fragmented production: Israel, Ireland and Taiwan. Enterprise \& Society, 7(4), 675-684.

Buhalis, D. (2000). Marketing the competitive destination of the future. Tourism Management, 21(1), 97-116.

Camisón, C., \& Monfort-Mir, V. M. (2012). Measuring innovation in tourism from the Schumpeterian and the dynamic-capabilities perspectives. Tourism Management, 33(4), 776-789.

Carlsen, J., Liburd, J., Edwards, D., \& Forde, P. (2008). Overview of innovation for sustainable tourism. In J. Carlsen, J. Liburd, D. Edwards, \& P. Forde (Eds.), Innovation for sustainable tourism: International case studies (pp. 3-14). Esbjerg, Denmark: BEST Education Network.

Christensen, P., McIntyre, N., \& Pikholz, L. (2002). Bridging community and economic development-A strategy for using indsutry clusters to link neighourhoods to the regional economy. Retrieved September 25, 2011, from http://www.shorebankcleveland.com/media/pdf/cluster.pdf

Coombs, R., \& Miles, I. (2000). Innovation, measurement and services: The new problematique. In J. S. Metcalfe \& I. Miles (Eds.), Innovation systems in the service economy. Measurement and case study analysis (pp. 85-104). Boston: Kluwer Academic.

Cooper, C. (2006). Knowledge management and tourism. Annals of Tourism Research, 33(1), 47-64.

Cooper, R. G. (2001). Winning at new products: Accelerating the process from idea to launch. Reading, MA: Perseus Publishing.

Crouch, G. I., \& Ritchie, J. R. B. (1999). Tourism, competitiveness and social prosperity. Journal of Business Research, 44(3), 137-152.

Dalum, B., Johnson, B., \& Lundvall, B. (1992). Public policy in the learning society. In B. Lundvall (Ed.), National systems of innovation: Towards a theory of innovation and interactive learning (pp. 296-317). New York: Pinter.

De la Vega, A. F. R., \& Stankosky, M. (2006). Knowledge management and innovation: What must governments do to increase innovation? Journal of Knowledge Management Practice, 7(4).

Dredge, D., \& Jenkins, J. M. (2007). The state, institutions and actors. In D. Dredge \& J. M. Jenkins (Eds.), Tourism planning and policy (pp. 32-68). Brisbane, Queensland, Australia: Wiley.

Dredge, D., Lamont, M. J., Ford, E., Phi, G., Whitford, M., \& Wynn-Moylan, P. (2010). Event governance: The rhetoric and reality of the World Rally Championship, Northern 
Rivers, NSW. Paper presented at the CAUTHE 2010: Challenge the Limits, Hobart, Tasmania, February 8-11.

Edquist, C., \& Lundvall, B. (1993). Comparing the Danish and Swedish systems of innovation. In R. R. Nelson (Ed.), National innovation systems: A comparative analysis (pp. 265-298). New York: Oxford University Press.

Etzkowitz, H. (2003). Innovation in innovation: The triple helix of university-industry-government relations. Social Science Information, 42(3), 293-337.

Faulkner, B., \& Tideswell, C. (2005). Rejuvenating a maturing tourist destination: The case of the Gold Coast, Australia. In R. W. Butler (Ed.), The tourism area life cycle (Vol. 1, pp. 306-335). Clevedon, UK: Channel View Publications.

Frechtling, D. C. (1999). The tourism satellite account: Foundations, progress and issues. Tourism Management, 20(1), 163-170.

Garcia, R., \& Calantone, R. J. (2002). A critical look at technological innovation typology and innovativeness terminology: A literature review. Journal of Product Innovation Management, 19(2), 110-132.

Hall, C. M. (2008). Tourism planning: Policies, processes and relationships (2nd ed.). Harlow, England: Prentice Hall.

Hall, C. M. (2009). Innovation and tourism policy in Australia and New Zealand: Never the twain shall meet. Journal of Policy Research in Tourism, Leisure and Events, 1(1), 2-18.

Hall, C. M., \& Williams, A. M. (2008). Tourism and innovation. London: Routledge.

Hassanien, A., \& Eid, R. (2007). Developing new products in the hospitality industry: A case of Egypt. Journal of Hospitality Marketing \& Management, 15(2), 33-53.

Henderson, K. A. (1991). Dimensions of choice: A qualitative approach to recreation, parks, and leisure research. State College, PA: Venture.

Hjalager, A.-M. (2002). Repairing innovation defectiveness in tourism. Tourism Management, 23(5), 465-474.

Hjalager, A.-M. (2009). Cultural tourism innovation systems-the Roskilde Festival. Scandinavian Journal of Hospitality and Tourism, 9(2-3), 266-287.

Hjalager, A.-M. (2010). A review of innovation research in tourism. Tourism Management, 31(1), 1-12.

Hjalager, A.-M., Huijbens, E. H., Björk, P., Nordin, S., Flagestad, A., \& Knutsson, Ö. (2008). Innovation systems in Nordic tourism. Oslo, Norway: Nordic Innovation Centre.

Hong, W. (2008). Competitiveness in the tourism sector: A comprehensive approach from economic and management points. New York: Springer.

Innovation Norway. (2008). White book for destination development. Oslo, Norway: Author.

Jeffries, D. (2001). Governments and tourism. Oxford, UK: Butterworth Heinemann.

Jennings, G. (2001). Tourism research. Milton, Queensland, Australia: Wiley.

Johne, A. (1996). Succeeding at product development involves more than avoiding failure. European Management Journal, 14(2), 176-180.
Keller, P. (2006). Innovation and tourism policy. In Innovation and growth in tourism (pp. 17-40). Paris: OECD.

Kelliher, F., \& Reinl, L. (2011). From facilitated to independent tourism learning networks: Connecting the dots. Tourism Planning \& Development, 8(2), 185-197.

Kim, W. C., \& Mauborgne, R. (1997). Value innovation: The strategic logic of high growth. Harvard Business Review, 75(1), 103-112.

Kleinschmidt, E. J., \& Cooper, R. G. (1991). The impact of product innovativeness on performance. Journal of Product Innovation Management, 8(4), 240-251.

Laange-Hellman, J. (1987). Process innovation through technical co-operation. In H. Hakanasson (Ed.), Industrial technological development. A network approach (pp. 26-83). London: Croom Helm.

Mahmood, I. P., \& Rufin, C. (2005). Government's dilemma: The role of government in imitation and innovation. Academy of Management Review, 30(2), 338-360.

McNabb, D. E. (2002). Research methods in public administration and nonprofit management: quantitative and qualitative approaches. Armonk, NY: M. E. Sharpe.

Metcalfe, S. (1994). Evolutionary economics and technology policy. The Economic Journal, 104, 931-944.

Morrison, A., \& Teixeria, R. (2004). Small business performance: A tourism sector focus. Journal of Small Business and Enterprise Development, 11(2), 166-173.

Moscardo, G. (2008). Sustainable tourism innovation: Challenging basic assumptions. Tourism and Hospitality Research, 8(1), 4-13.

Myers, M. D. (2009). Qualitative research in business management. Wiltshire, UK: Sage.

Neuman, W. L. (2006). Social research methods: Qualitative and qualitative approaches (6th ed.). Boston: Pearson.

Norwegian Ministry of Trade and Industry. (2007). Valuable experiences. Oslo, Norway: Author.

Norwegian Ministry of Trade and Industry. (2010). Proposition No. 1S-For the budget year 2011. Oslo, Norway: Author.

Nohria, N., \& Gulati, R. (1996). Is slack good or bad for innovation? Academy of Management Journal, 39(5), 1245-1264.

Nordin, S., \& Svensson, B. (2005). The significance of governance in innovative tourism destinations. Paper presented at the Innovation in Tourism-Creating the Customer Value, St-Gallen.

Novelli, M., Schmitz, B., \& Spencer, T. (2006). Networks, clusters and innovation in tourism: A UK experience. Tourism Management, 27(1), 1141-1152.

Organization for Economic Cooperation and Development. (2006). Innovation and growth in tourism. Paris: Author.

Paget, E., Dimanche, F., \& Mounet, J.-P. (2010). A tourism innovation case: An actor-network approach. Annals of Tourism Research 37(3), 828-847.

Patton, M. Q. (1990). Qualitative evaluation and research methods. Newbury Park, CA: Sage.

Pechlaner, H., Fischer, E., \& Hammann, E. (2005). Leadership and innovation processes-Development of products and services based on core competencies. In M. Peters 
\& B. Pikkemaat (Eds.), Innovation in hospitality and tourism (pp. 31-57). New York: Haworth Hospitality Press.

Poon, A. (1993). Tourism, technology and competitive strategies. Wallingford, UK: Oxon.

Presenza, A., \& Cipollina, M. (2010). Analysing tourism stakeholders networks. Tourism Review, 65(4), 17-30.

Rodrik, D. (1996). Coordination failures and government policy: A model with application to East Asia and Eastern Europe. Journal of International Economics, 40(1), $1-22$.

Romeiro, P., \& Costa, C. (2010). The potential of management networkds in the innovation and competitiveness of rural tourism: A case study on the Valle del Jerte (Spain). Current Issues in Tourism, 13(1), 75-91.
Roper, S., \& Crone, M. (2003). Knowledge complimentarity and coordination in the local supply chain: Some empirical evidence. British Journal of Management, 14(1), 339-355.

Schumpeter, J. (1934). The theory of economic development: An inquiry into profits, capital, credit, interest, and the business cycle. Cambridge, MA: Harvard University Press.

Storey, J., \& Salaman, G. (2005). Managers of innovation: Insights into making innovation happen. Cornwall: Blackwell Publishing.

Utterback, J. M. (1994). Mastering the dynamics of innovation. Boston: Harvard Business School Press.

Van de Ven, A. H., Polley, D. E., Garud, R., \& Venkataraman, S. (1999). The innovation journey. New York: Oxford University Press. 